This is the version of the article accepted for publication in International Political Sociology published by Oxford University Press: https://academic.oup.com/ips

Accepted version downloaded from SOAS Research Online: http://eprints.soas.ac.uk/25890

\title{
PROFESSIONALISING PROTEST: SCIENTIFIC CAPITAL AND ADVOCACY IN TRADE POLITICS ${ }^{1}$
}

\author{
Matthew Eagleton-Pierce \\ SOAS University of London \\ Senior Lecturer in International Political Economy \\ Email: m.eagleton-pierce@soas.ac.uk \\ Forthcoming in International Political Sociology
}

\begin{abstract}
A range of socio-economic dislocations have spawned renewed interest in the capitalist system and its critiques. Within these trends, the politics of international trade has often been a flashpoint for civil society organisations (CSOs) concerned with social justice. This paper uncovers a neglected feature of this landscape: how, since the 1980s, certain CSOs have shifted from being 'radical outsiders' to 'reformist insiders' to protest the design and purpose of global trade. We know why CSOs have criticised the political economy of trade, but less about how they have historically struggled to gain admission into this policy milieu; their internal strategising and tensions; and what makes for effective protest. To understand such experimentation, this paper argues that literature on professionalisation offers a valuable lens for exploring the relationship between expertise and power. Dovetailing with other research in IPS, it adapts Bourdieu's comparatively underused concept of scientific capital to explicate how certain, prized dispositional qualities were acquired and practiced for the purpose of registering policy impact. This argument is developed through the case of Oxfam. When viewed historically, the paper suggests that a professionalised, activist subjectivity has emerged within certain CSOs, defined here under a new ideal-type notion of the 'critical technician'.
\end{abstract}

\section{Keywords}

Professionalisation, Scientific Capital, Bourdieu, Civil Society, International Trade

\section{Word count}

11,822

\footnotetext{
${ }^{1}$ Previous versions of this article were presented at seminars in 2017 hosted by the International Political Economy Research Workshop at the London School of Economics, and the Politics and International Relations Seminar Series at Cardiff University. In particular, I wish to thank the very productive engagements with Stephen Woolcock, James Morrison, Oksana Levkovych, Alena Drieschova, Sara Dezalay, and Hannah Hughes. In 2016, an earlier draft was presented at the International Studies Association Annual Convention in Atlanta. On the theme of trade policy expertise, I have been helped by the ongoing insightful analysis produced by James Scott, Erin Hannah, and Silke Trommer. I am very thankful for the time taken by the interview subjects, the conversations of which greatly aided my understanding. Finally, I am grateful to the reviewers and editors of International Political Sociology for their supportive and constructive comments. These debts notwithstanding, I remain responsible for the content and for any mistakes I may have made.
} 
In recent years, a range of socio-economic dislocations - including the fall-out from the global financial crisis; material inequities in many countries; and contestations around populism - have spawned renewed interest in the capitalist system and its critiques (Boltanski and Chiapello 2006; Gamble 2014; Streeck 2014, 2016). Within these larger trends, the politics of international trade has often been a flashpoint for a range of civil society organisations (CSOs) concerned with social justice. Through contesting why the structures and rules of the trading system often take uneven political and distributional forms, CSOs have problematised trade diplomacy for many governments and international organisations. This paper uncovers a neglected feature of this landscape: how, since the 1980s, certain CSOs have shifted from being 'radical outsiders' to 'reformist insiders' in order to protest the design and purpose of global trade. We know why CSOs have criticised the political economy of commercial exchange, but much less about how they have historically struggled to gain admission into this particular policy milieu; their internal strategising and tensions; and what makes for effective protest. In order to understand such experimentation, this paper argues that the literature on the politics of professionalisation offers a valuable lens for exploring the relationship between expertise and power. Dovetailing with other research in international political sociology (IPS), it adapts Pierre Bourdieu's comparatively underused concept of scientific capital in order to explicate how certain, prized dispositional qualities were acquired and practiced for the purpose of registering policy impact. The paper develops this argument through a case study on Oxfam. When viewed historically, I suggest in conclusion that a particular professionalised, activist subjectivity has emerged within certain CSOs, defined here under a new ideal-type notion of the 'critical technician'.

Within political economy, law, and sociology, scholars have addressed different enquiries related to the links between social justice activism and trade politics. At a macro-level, some authors have explored 'fair trade' or 'global justice' social movements (Della Porta 2007; Raynolds, Murray, and Wilkinson 2007; 
Lang 2011). Other researchers have traced how CSOs have gained access to particular policy mechanisms, such as through the World Trade Organisation (WTO) or the European Union (EU) (Dür and Bièvre 2007; Hannah 2016). Further studies have explored the impact of CSO activism on specific traderelated areas, including labour standards, investment, or intellectual property rules (Murphy 2010). Together, these contributions aid our understanding of the political contestability of trade regulation, but all tend to be weaker in two aspects. In one sense, there is a paucity of analysis on how struggles have played out behind the scenes in particular CSOs and within their social networks. In other words, evaluating the larger question of CSO conduct and effectiveness can only be adequately understood through combining an assessment of internal deliberation with external repercussions. Like other societal institutions, CSOs tend to project an image of coherence, purpose and control, even when their working environment may feature frequent disputes or cloudy objectives. In another respect, the coverage of CSO engagement with global trade policy often misses an historical appreciation for how advocacy politics change over time. As I will argue, since the 1980s, the power exercised by major CSOs in the trade policy space has been nurtured and tested in ways that were not necessarily predictable. Tracing this history is a worthy enquiry because it helps to reveal gradual processes of adaptation to dominant agendas and subjectivities in capitalism which may be missed if one remains preoccupied with current events.

To excavate this empirical terrain, the paper develops a particular conceptual approach of relevance to IPS, one which is attentive to the relations between, on the one hand, forms of power and, on the other, professions and processes of professionalisation. The study of professionalism has been a long-standing concern in sociology (Parsons 1939; Goode 1969; Larson 1977; Abbott 1988; Freidson 2001). In recent decades, this foundational literature has offered a springboard for other researchers to examine 'expert' or 'knowledge-based' forms of governance (Gorman and Sandefur 2011). For instance, in international relations (IR) and international political economy (IPE), the literature on epistemic communities (Haas 1992, 2016; Cross 2013) helped to fashion an analytical framework for studying how expert networks form 
'authoritative claims to policy-relevant knowledge' (Haas 1992: 3). Elsewhere, more recently, Didier Bigo $(2011,2016)$ has advanced the concept of 'transnational guilds of professionals' to denote those circuits of public and private actors who reconfigure fields of power, operating in ways which contest conventional politics and common meanings of where agency is located (also see Sending 2015; in addition, Kennedy 2016). Understanding the mechanisms of professionalisation in transnational governance has been further deepened through Seabrooke and Henriksen (2017), a volume which charts how to plot and theorise the relations between types of organisations and practices of professionalism. The argument in this paper draws inspiration from these writings, but also seeks to advance a Bourdieusian-weighed analytical framework for explaining how the wider culture of professionalisation has now sedimented into many spaces beyond the classic concerns of (national and international) bureaucracies which are covered in these literatures.

At the intersection between these two bodies of scholarship, there are some authors who have examined what I term the professionalisation of protest in the trade policy arena. Most notably, Kristen Hopewell has astutely argued that some major civil society groups interested in the governance of the WTO 'have been drawn towards increasingly technocratic and neoliberal forms of advocacy' (Hopewell 2015: 1151). She illustrates this through attention to the working practices of such actors, including a normative preference for trade liberalisation and the deployment of legal and economic analysis within research endeavors. Other studies have explored similar themes, including Erin Hannah's notion of 'embedded NGOs' who 'accept the basic tenets of free trade', yet try to utilise existing policy ideas to empower marginalised actors (Hannah 2014: 459). One can also note the particular examination of intellectuals in the global political economy of trade and how such figures have sometimes been utilised by advocacy groups (Scott 2015; more generally on expertise, see Hannah, Scott, and Trommer 2016). While both Hopewell (2015) and Hannah (2014) examine how certain civil society groups leverage 'policyrelevant', technical expertise, often in the service of marginalised countries in the WTO system, my chief starting point in this article is the very historical construction of such authority since the 1980 s, a context which has been so far 
underdeveloped. ${ }^{2}$ This article also makes a distinctive contribution through a detailed exploration around Oxfam's trade campaigning history and, in addition, develops a mid-range conceptual tool designed to illuminate some of the wider behavioural tendencies of modern activism within professional settings. In the process, therefore, I suggest that the theoretical insights developed here go beyond the particular case of trade policy and have wider application. Ultimately, this paper therefore aims to contribute to larger discussions in IPS on democratic expression in the remaking of global politics, including the problem of how CSOs have tried to enlarge the scope for deliberation, contestability, and impact.

The paper is divided into four sections. In the first section, I contextualise the discussion on professionalisation through an engagement with theoretical issues, including an outline of the utility of the scientific capital framework. In the second section, I begin the examination of the case of Oxfam's trade policy advocacy through the prism of scientific capital. In the shadow of the transition from the General Agreement on Tariffs and Trade (GATT) to the WTO system, set within the period from the mid-1980s to the mid-1990s, I explore how and why Oxfam tended to occupy a marginalised position in trade policy debates. In the third section, I turn to address a prominent Oxfam campaign around the turn of the century called Make Trade Fair. Within this period, the culture of professionalisation was maturing within the organisation, to the extent that Oxfam acquired greater recognition from authorised experts and bodies, but also notable criticism. Derived from this empirical enquiry, the final section offers a brief outline of the critical technician notion for better understanding what behavioural attributes are prized within this particular social space of 'reformist advocacy'.

\section{PROFESSIONALISATION, EXPERTISE, AND SCIENTIFIC CAPITAL}

\footnotetext{
2 For instance, in Hannah's (2014) account, she views her category of 'embedded NGOs' as largely emerging from the Monterrey Consensus on Financing for Development in 2002. My conceptualisation in this article adopts as a wider lens, both in respect to historical development and the contemporary spreading of professionalised standards of comportment among societal actors.
} 
From classic studies within sociology to more recent analysis of knowledgebased work, scholarship on professionalisation has tended to define the subject in relation to four major themes: (1) the production of expertise; (2) technical autonomy; (3) a normative orientation towards the service of others; and (4) high status, income and other rewards (Gorman and Sandefur 2011). This article features a particular focus on the first of these factors since, as it has often been remarked, the creation and social reproduction of expert knowledge is the sine qua non of professional activity. All persons that are named, or selfidentify as, experts seek the authority to engage with targeted audiences. To different degrees, they diagnose, infer, and treat problems of governance that are judged to be socially important (Abbott 1988). Within IPE, understanding the politics of policy expertise has been a reoccurring theme, as many constructivist-leaning authors have debated in respect to a range of empirical topics (McNamara 1999; Blyth 2002; Barnett and Finnemore 2004; Best 2005, 2014; Sinclair 2005; Abdelal, Blyth, and Parsons 2010; Chwieroth 2010). Together, these studies help us to explain why and how particular theories, agendas, and modes of reasoning acquire a legitimised power and who benefits from such privileging, along with attention to how forms of social critique may contest and, in certain cases, reshape dominant policy orthodoxies.

This paper builds upon such literature, but is also distinctive for charting how other entities in world politics - beyond the common focus on state agencies, international institutions, and corporate groups - learn how to acquire 'authentic' practices associated with modern professionalism. Such forms of learning are, in part, shaped by whatever is intersubjectively valued as the most desirable forms of capital within particular social spaces, the historical struggles of which will tend to be informed by those agents who are more capable of reproducing the dominant culture. For instance, some researchers have argued how the growth of large CSOs has been accompanied by a 'privatisation of politics' (Hilton et al. 2013) or, in particular cases, a 'corporatization of activism' (Jordan and Maloney 1997; Dauvergne and LeBaron 2014). Such literature has been alert to the implicit or explicit importing of managerial thinking into CSOs, including how ideas on efficiency, accountability, branding, and benchmarking 
shape what counts as appropriate advocacy action (Roberts, Jones, and Fröhling 2005; Lewis 2007; Dar and Cooke 2008; Seabrooke and Wigan 2015). In short, my argument seeks to examine how civil society agents who have been historically marginalised in policy deliberations - relative to governments, firms, or lobby associations - have laboured to build the necessary forms of expertise to speak with authority and, thus, acquire the socio-political recognition of becoming an expert. When successful, these agents may, indeed, be considered 'expert-activists' (Seabrooke and Wigan 2015). While the influence of corporate power and ideology on major CSOs has certainly increased since the 1990s, in contrast to Dauvergne and LeBaron (2014), I view the nurturing of a professional culture as a wider trend of social comportment which cannot be easily captured under the label of 'corporatization' emanating from private sector actors.

Inspired by work on professionalisation within IPS, this paper agrees with Sending's (2015) starting proposition that the 'question of whether and how expert groups may shape policy is subordinate to the question of the type and contents of knowledge that prevail as authoritative in shaping debates about what should be governed, how, and why' (Sending 2015: 8). In the context of international trade policy, I explore, in the spirit of Dezalay and Garth's (2002, 2011) analysis of professional rivalries, the enduring significance of economic and legal expertise as disciplinary bodies inscribed in the struggle over the universal (also see Fourcade 2006, 2010; Dezalay and Madsen 2017; Seabrooke and Henriksen 2017). I am interested here in not only how CSOs may contest such knowledge, but also how their working practices and, at times, normative inclinations may align with similar thinking and conduct found in conventional bureaucratic agencies of authority, in the process forming part of a wider 'transnational power elite' (Kauppi and Madsen 2013, 2014). The argument also shares some affinity with Bigo's (2016) concept of 'transnational guilds' of professionals: first, for the attention to how agents try to master whatever is judged to constitute the methods of their 'artisanal craft'; and second, for how a sense of cross-border solidarity is stimulated through association with the 'guild' in question. Although the empirical discussion here does not map a trade policy-related transnational guild, the research is 
motivated by a larger concern for understanding the 'international political economy roots' of such relations in the neoliberal period, including the 'entanglement between public and private agents who are bureaucrats on both sides' (Bigo 2016: 412).

To enrich the empirics, my argument makes use of a framework which is alert to the uneven relations between expertise and power: Bourdieu's relatively underexplored notion of scientific capital (see partial exceptions in IPS by Bernhard 2011; Berling 2015). This concept was originally formulated in his sociology of science and the evaluation of what he calls the scientific field (Bourdieu 1975, 1991, 2004). In strict Bourdieu usage, scientific capital functions as a form of symbolic power in the wider politics of social recognition and legitimacy production. ${ }^{3}$ To explain the utility of scientific capital, three aspects can be highlighted. First, by associating 'science' with 'capital', it helps to foreground how the production of expertise is shaped by a panoply of power relations, ranging from explicit requirements to more subtle sleights of hand. While this core point is accepted by many, including IR constructivists (for instance, see Barnett and Finnemore 2004; Best 2014), Bourdieu suggests that one still needs to guard against any 'irenic' depiction of experts engaged in a so-called 'perfect competition of ideas, a contest infallibly decided by the intrinsic strength of the true idea' (Bourdieu 1975: 19). Instead, all references to 'technical' or, particularly in our current period, 'global' competence and reason bare the imprint of politics. Within the social construction of scientific capital, there are obviously gradations of politicisation in how policy-facing professionals work and perceive their actions; the definition of any 'interest' is, therefore, neither purely 'political' nor purely 'intellectual'. Indeed, it is precisely because social agents feature multilayered and dynamic schemas - a habitus which can conflate and often confuse the particular with the universal - which makes the study of scientific capital a worthy enquiry.

\footnotetext{
3 To be clear, I am applying this concept as an abstracted reference to what is presumed to be objective, often positivist, principles of knowledge and argumentation, and not in the sense that the civil society representatives under study here are qualified natural scientists.
} 
Second, Bourdieu includes a wide variety of objects and processes as being implicated in the uneven generation of scientific capital and the making of 'normal' professional conduct. In one sense, as noted, this includes attention to disciplinary knowledge and how the earning of degrees, such as from institutions recognised as 'prestigious', offers a socially consecrated passport for the agent to enter into milieus where the scientific capital is valorised (for instance, see Chwieroth (2010) on the relationship between Ivy League universities and IMF staff recruitment). For CSO analysts who desire to shape the stakes of the trade policy game, a qualification in economics, law, or development studies represents an initial, objectified form of scientific capital. A Bourdieusian perspective is also analytically sensitive in another respect: that is, for observing how scientific capital is 'marked by an elaborate apparatus of emblems and signs' (Bourdieu 1975: 20). Distinctively in relation to the existing literature, I translate and extend this particular theme through examining what could be commonly called the presentational or campaigning aspects of modern CSO professionalism. The aim here is to explore how the cultivation of scientific capital proceeds not only through the command of orthodox policy expertise and, in particular, the use of quantifiable knowledge, but also via the reformulation of data into narratives, headline messages, and visual content. Indeed, mastering these latter skills is a crucial feature of how the activist appeals to multiple audiences, including the non-expert, in a reoccuring pattern which is similar to Seabrooke's (2014) notion of 'identity switching'. Thus, scientific capital can carry important effects - such as via popular emotional incitement and group mobilisation - even if the targeted audience has not understood, or actively engaged with, the precise empirical content of the argument in question. It can be debated if these effects, at a deeper level, are now reconfiguring what is socially judged to be a legitimate or persuasive policy-related argument.

Third, the notion of scientific capital can also be used as a vehicle for exploring the differences between succession and subversion strategies in the struggle to accumulate professional authority. This aspect is particularly valuable for my empirical content which is focused on how 'new entrants' to the trade policy game have tried to contest the organisation and normative basis of international 
commerce. For Bourdieu, new pretenders to a field can adopt a succession strategy, whereby they build relations with established experts, offer 'limited innovations within authorised limits', and await the likelihood of acquiring scientific profits of distinction. By contrast, a subversion strategy, premised on 'more costly and more hazardous investments' of heterodox critique, will tend to increase risk, particularly if it involves problematising core principles. It follows, therefore, that 'newcomers who refuse the beaten tracks cannot "beat the dominant at their own game" unless they make additional, strictly scientific investments from which they cannot expect high profits, at least in the short run, since the whole logic of the system is against them' (Bourdieu 1975: 30; also see Bourdieu 1991). Here, I would like to develop this argument, but also suggest that shades of grey exist between succession and subversion methods, including circumstances where it may be unclear which is the most significant orientation. In addition, one may also witness a conservation strategy on the part of an actor who was subversive at an earlier stage in history. I argue that the tension between these main strategic tendencies of action stems from the social pressure on new entrants to acquire and sustain recognition while, at the same time, cultivating a political critique which remains 'comprehensible' within the core of the field.

Although the focus in this paper is on scientific capital as a form of power, I acknowledge that other species and structures of power shape outcomes in trade policy activism. The following analysis makes note of how, for instance, economic capital to fund extensive trade policy campaigns within a large CSO is obviously significant when compared to smaller entities with more limited budgets. In addition, the social capital derived from acquiring a durable network of connections and ties of appreciation - within governments, international bodies, domestic social groups, and the media - also informs the potential effectiveness of any CSO campaign. The relations between economic, social, and scientific capital would, indeed, constitute a richer examination, but one which would expand beyond the confines of the space here. Through foregrounding the struggle over scientific capital, my aim is to further dissect the relations between expertise and power in the making of modern professionalism. With these conceptual issues in mind, we can turn to the 
empirical case on Oxfam within the social world of international trade policy activism.

Within the two main empirical sections which follow, I draw upon primary and secondary data to examine the case of Oxfam's trade policy advocacy through the conceptual category of scientific capital. The research is derived from three main sources: (1) interviews with 20 subjects, including past and present Oxfam representatives, independent consultants who have worked for CSOs, and WTO Secretariat representatives; (2) reports and internal communications extracted from the Oxfam Archives at the Bodleian Library, Oxford; and (3) secondary academic literature. The discussion explores how Oxfam steadily emerged as a voice in trade policy activism, noting in particular the research content and presentation techniques used to nurture forms of professional authority. To illuminate how the group struggled to adapt to the international trade policy game, I first plot the period from the mid-1980s to the mid-1990s. This phase highlights how Oxfam was experimenting with certain indicators of professional conduct yet, at the same time, did not generate much concrete impact on wider trade policy debates and rules. In section four, by way of comparison, I concentrate on a particular illustration drawn from the early 2000s: the making of a major trade policy report and campaign. Within this discussion, I dissect some of the major features of scientific capital and how Oxfam struggled to carve out a recognisable space for protest and dialogue which continues today.

\section{THE STRUGGLE TO ENTER THE TRADE POLICY GAME}

In order to grasp the stakes and implications of this discussion, one needs some context on the larger professional population of trade policy experts. In the postWW2 period, in the shadow of the GATT as the major body of law informing the reconstruction of a Western-centred capitalism, the social world of trade experts took on an enclosed quality. The esoteric, at times impenetrably dry subject matter of trade - such as debating the finer points of tariff schedules or anti-dumping codes - often did not enhance the prospect of dialogue between 
government departments, never mind broader public deliberation and critical academic scrutiny. The cultivation of such insularity led, in Robert Howse's (2002: 98) words, to the making of a particular transnational 'elite' or 'insider network'. Since the 1970s, one could suggest that the composition of this network has broadened, such as in response to the incorporation of new states and investment in diplomatic trade missions, while remaining relatively coherent in terms of disciplinary biases (economics and law), normative predilections (trade liberalisation as generally beneficial), and technocratic impulses (limits on accountability). Core experts within this elite would include: employees within the GATT/WTO system, delegates from influential governments, domestic trade officials with a remit in commercial agendas, other international institutions with a trade brief (such as the World Bank or OECD), along with policy-facing academics and private practitioners (Howse and Nicolaïdis 2008). ${ }^{4}$ Although it would be wrong to depict the agents in this universe as either completely homogenous in their visions or organised according to some calculated and codified plan, there is still a loose liberal ethos and practical 'sense of the game' regarding what problems of global trade merit analytical attention and how they should be treated. Unsurprisingly, once socialised into the space, solidarity tends to consolidate through a sense of collegiality, friendship, and various 'self-referential' cues, although this should not be taken to mean that personal rivalries are non-existent (Weiler 2001: 336; also see Xu and Weller 2004; Pauwelyn 2005; Marceau 2015).

Whether this insider network constitutes a field in the Bourdieusian sense can be debated but, at the very least, it forms a distinctive social setting of experts who govern, to different degrees, a significant regulatory space of global capitalism. For newcomers in civil society groups who seek any kind of effective participation in this space, they confront a number of entry requirements and obstacles. In parallel, or sometimes even prior to, the problem of how to master relevant policy expertise and devise strategies for 'selling' alternative propositions to different audiences, new entrants, as relative outsiders, have

\footnotetext{
${ }^{4}$ For an illustration of figures within this network, see the biographical data on 106 prominent persons associated with the history of the GATT/WTO system in VanGrasstek, C., The History and Future of the World Trade Organization (Geneva: WTO, 2013), 571-598.
} 
often been preoccupied about transparency problems. In the context of the club-like GATT culture, with its aura of aristocratic-like discretion, trade diplomacy, in part a reflection of diplomatic conduct in general, has historically be shaped by secrecy or limits on the public disclosure of information (Curzon and Curzon 1973; Keohane and Nye 2001; for a review, see Lamp 2016). This legacy continued into the contemporary system of trade diplomacy including, but also beyond, the WTO arena. ${ }^{5}$ The recourse to informality in decisionmaking and rule setting has also been a major grievance of many developing countries who largely, although not entirely, tended to lack the capacity of Western governments (Jawara and Kwa 2004; Jones 2009; Narlikar 2012). It follows, therefore, that one immediate and fundamental problem faced by CSOs - particularly in the context of the 1980s and 1990s which I trace below - was how to decipher the basic contours and direction of the trade policy agenda (including all the detail on mandates, negotiation texts, and lobbying interests within a wider labyrinth of politics).

This context should not be taken to mean that the post-WW2 trading regime was hermetically sealed from social critique, including the voice of certain CSOs. The GATT agenda, along with the intellectual orthodoxy of trade theory, was problematised by a range of individuals and institutions which, in turn, would provide an epistemic foundation for the strengthening of CSO activism at the turn of the century. For instance, the establishment of the United Nations Conference on Trade and Development (UNCTAD) in 1964, led by Raúl Prebisch and Wladyslaw Malinowski, was explicit in scrutinising how injustices in the world economy were the product of rulemaking structures between rich and poor countries. In addition to its intellectual work as a critical knowledge producer, UNCTAD led the creation of the Group of 77 and succeeded in reforming trade rules to allow developing countries preferential access to developed countries markets (Tussie 1987; UNCTAD 2004; Taylor and Smith

\footnotetext{
${ }^{5}$ For example, the early WTO continued the restrictive, GATT-era practice of withholding documents related to decision-making and negotiations. By 1996, encouraged by groups such as the Geneva-based International Centre for Trade and Sustainable Development (ICTSD), the WTO membership agreed to gradually de-restrict documents. This seemingly unremarkable decision of bureaucratic management would prove significant in allowing more light to be shed on WTO politics and thus, in turn, increase the potential for research-intensive, civil society actors to develop critiques of the organisation.
} 
2007; Hannah and Scott 2017). ${ }^{6}$ From the early 1970s, UNCTAD was also the institutional hub for the promotion of the New International Economic Order (NIEO), an umbrella term for debating pervasive North-South inequities within economic policies, negotiation processes, historical structures, and systems of knowledge (Cox 1979; Murphy 1984). During this period of Third Worldism, the 'NIEO imaginary' also served as a catalyst for CSOs, such as War on Want, who campaigned for a more just capitalist system via the narrative of a 'common humanity' (O'Sullivan 2015). With these major aspects of the social history of international trade politics in mind, we can turn to the particular case of how Oxfam sought a more prominent voice.

From the mid-1980s to the late-1990s, within Europe, North America and elsewhere, the inherent political content of international trade policy acquired a wider resonance. During this period, a number of CSOs had concerns regarding trade policy, but also viewed such problems as being intertwined with development, aid, and debt politics. It is worth noting that this holistic vision often tended to mirror the general policy orientation of UNCTAD, whose research outputs continued to be more favourably read by many CSO analysts. Examples of prominent networks of CSOs at this time include the European Solidarity Towards Equal Participation of People (EUROSTEP) and the International Cooperation for Development and Solidarity (EURO-CIDSE). Such collectives began to mobilise over the GATT Uruguay Round (1986-94) of trade talks and worked primarily through the NGO-GATT Steering Committee. The UK was a key centre for CSOs who carved out a stake in trade policy, including activism by the Catholic Institute for International Relations (CIIR) and Christian Aid (Wilkinson 1996; Lang 2011). From 1994, with the signing of the North American Free Trade Agreement (NAFTA) and the founding of the WTO, public debate over an expanding trade agenda became increasingly visible within many polities, such as the US, Canada, France, Germany, and the Netherlands. In the EU in particular, such interest generated

\footnotetext{
${ }^{6}$ The major trade policy reform generated by UNCTAD was the establishment of the Generalized System of Preferences (GSP) in 1970. By 1979, this policy innovation was incorporated by the GATT (via the Enabling Clause) to become a permanent legal resource. GSP schemes were subseqently introduced in many developed countries: by the mid-1990s, developing countries received trade preferences for their exports to developed countries amounting to approximately $\$ 80$ billion per year (UNCTAD 2004).
} 
a shift in how the trade-related CSOs were addressed, including an emphasis on 'partnership' initiatives led by the Commission (Meunier 2003; Hocking 2004; Kohler-Koch and Finke 2007).

Oxfam has always had a prominent position within this civil society landscape and, in some respects, could be viewed as an atypical case due to its size and international reach. Prior to 1995, a year when Oxfam International was formed as an overarching secretariat body, the group was comprised of 12 largely autonomous, nationally-focused affiliates (such as Oxfam GB, Oxfam America, and Oxfam India; internally referred to as 'Oxfams'). ${ }^{7}$ These entities continue to have degrees of operational freedom within a confederation structure. In the UK, Oxfam GB has consistently been among the richest charities, registering an income of $£ 51$ million in 1984-85, $£ 69$ million in 1990-91, before reaching $£ 187$ million in 2000-01 (Black 1992; Oxfam Annual Report and Accounts 2001). As illustrated in Figure 1, this income growth has steadily risen, surpassing $£ 300$ million by 2008-09. Figure 2 showcases the corresponding increase in staff recruitment in the group, including a doubling of Oxfam GB staff numbers from 1989 to 2009 (Hilton et al. 2012). From the mid-1980s to the millennium, most of Oxfam's spending was devoted to conventional forms of development assistance in developing countries, notably its well known humanitarian relief and aid operations aimed at eliminating poverty and forms of injustice. Expenditure devoted to 'advocacy' - defined as activities around research, education, lobbying, and campaigning - was much less. According to one estimate, in 1984, Oxfam GB devoted 4.4 per cent of total expenditure to advocacy, a figure that rose to 6.7 per cent by 1996 (Anderson 2007). Nevertheless, in the wider picture, due to the overall increase in Oxfam's income over this period, spending on advocacy-related work increased substantially and, in addition, was often larger than other comparable CSOs.

When one turns to Oxfam's relationship to trade policy, the second half of the 1980s featured few publications specifically focused on trade issues. Instead,

\footnotetext{
${ }^{7}$ As of 2017, there are 19 affiliates: Oxfam America, Oxfam Australia, Oxfam-in-Belgium, Oxfam Canada, Oxfam IBIS (Denmark), Oxfam France, Oxfam Germany, Oxfam GB, Oxfam Hong Kong, Oxfam India, Oxfam Intermón (Spain), Oxfam Ireland, Oxfam Italy, Oxfam Japan, Oxfam Mexico, Oxfam New Zealand, Oxfam Novib (Netherlands), Oxfam-Québec, and Oxfam South Africa.
} 
as noted, trade policy was often embedded within a general conversation on aid and debt politics (particularly as related to IMF and World Bank structural adjustment policies). In the wake of the Cambodian and Ethiopian crises, under

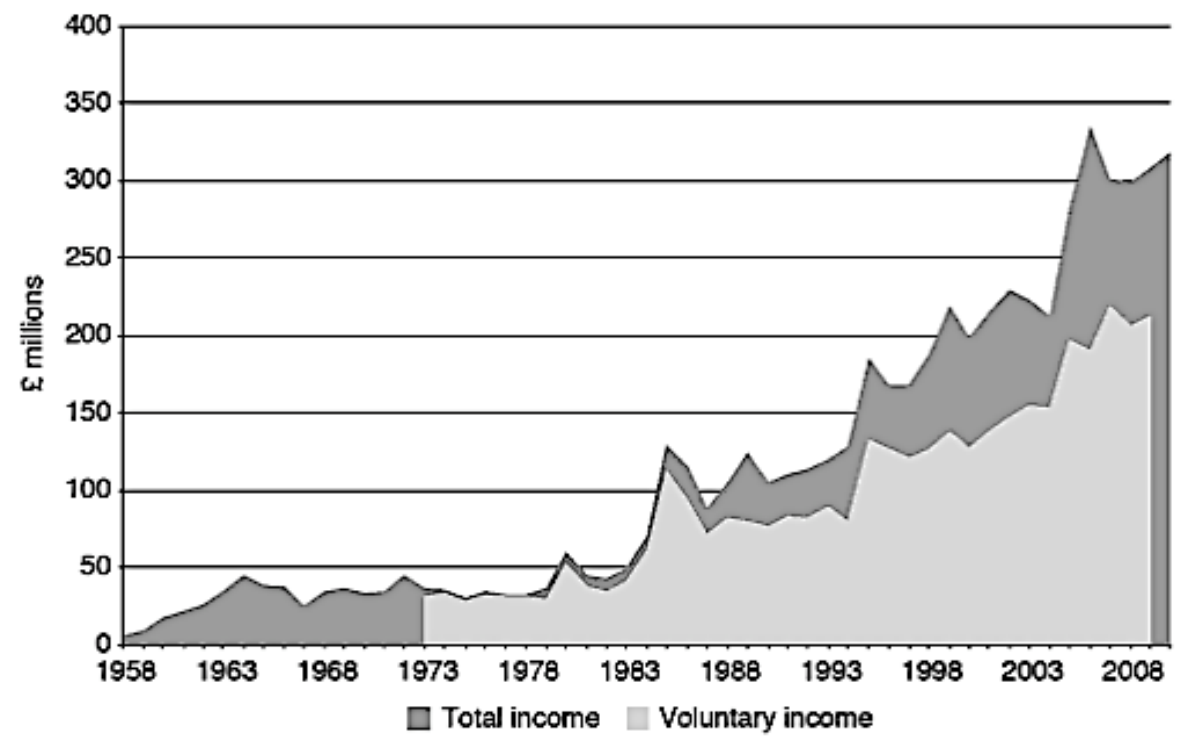

Figure 1 Voluntary and total income of Oxfam, 1958-2010 (adjusted for inflation, 2009). Source: Hilton et al. (2012): 184.

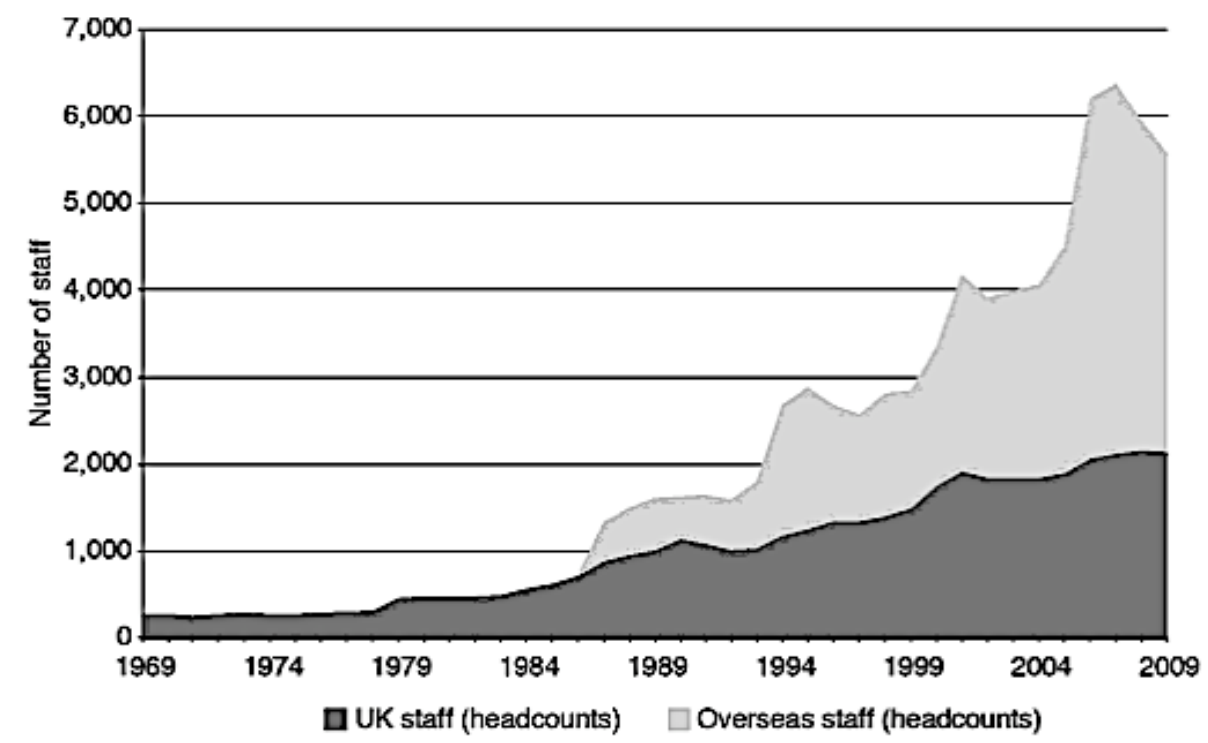

Figure 2 Number of staff working for Oxfam, 1969-2009. Source: Hilton et al. (2012): 185.

the directorship of Frank Judd (1985-91), Oxfam GB began to make further investments in research capacity. Similar to contemporary activism, these efforts were targeted at Oxfam's own supporters who, in turn, would help to 
assist in fundraising. For instance, Belinda Coote's (1987) book-length study on the sugar industry, including how EU overproduction negatively impacted developing country producers, represents the first detailed, Oxfam-produced critique on a particular commodity. In addition to other reports under the 'Hungry for Change' campaign, I would suggest that we see here the making of a basic template which would guide aspects of future research projects. Three issues are worth noting. First, the idea of an occasional overview report is established, one that synthesizes together problems, before offering policy recommendations (Twose 1984; Clark 1986). Second, these publications experiment with different forms of evidence in an effort to stir and persuade the reader, including drawing upon Oxfam's own field officers, data from international institutions, and other literature. Descriptive statistics is often given a prominent position along with case study boxes and photos. Third, memorable one-liners are penned in an effort to encapsulate some form of injustice, such as: 'For every $£ 1$ the world contributed to famine relief in Africa in 1985, the West took back $£ 2$ in debt repayment' (Black 1992: 269).

However, by the early 1990s, despite this activity, some individuals were registering a sense of unease at a disconnect between the expanding trade policy agenda within the Uruguay Round and the response of Oxfam and other CSOs (Wilkinson 1996; see also Clark 1992; Edwards 1993). In this context, the particular contribution of Kevin Watkins needs to be highlighted as being significant. ${ }^{8}$ In 1991, Watkins joined Oxfam from CIIR, rising from a Policy Analyst to Head of Research. Watkins argued that activists had failed to adequately monitor and critique the distribution consequences of existing trade rules and the new GATT programme. As he expressed it: 'When I joined Oxfam, NGO advocacy on trade was very limited both in terms of its ambition and approach'. 9 Watkins was concerned that CSO trade analysis tended to have a predominate focus around terms of trade in agriculture and OECD surpluses which, while being important, overlooked the expanding GATT agenda around

\footnotetext{
8 In terms of educational background, Watkins was awarded a BA in Politics and Social Science from Durham University in 1974. In 1986, he earned a DPhil from the University of Oxford for a thesis titled: 'India: Colonialism, Nationalism and Perceptions of Development'.

${ }^{9}$ Kevin Watkins, former Head of Research, Oxford International, interview with the author, Oxford, June 13, 2011.
} 
textiles, services, intellectual property, and investment (for instance, see Watkins 1992; and Coote 1992). This point has been noted by other Oxfam representatives who suggest that the GATT was often treated as an 'obscure' regime of law, one which was difficult to penetrate. ${ }^{10}$ While CSOs offered studies around some agricultural commodities, they did not have the capacity to evaluate the effects of the GATT agenda as an integrated package, leading to arguments that were often dismissed by officials as being 'overly-simplistic' or even 'Luddite' (on relations with the European Commission, see Wilkinson 1996). ${ }^{11}$ Importantly, at a normative level, Watkins was against 'anti-trade' or 'anti-markets' reasoning which was heard within some quarters of Oxfam (a legacy of the attraction for some of dependency theory and Latin American structuralist economics). Instead, he suggested that it was possible, within certain limits, if you could work the system effectively, to secure small gains in market access for developing countries'. It was this more moderate, 'reformist' disposition, one that called for dissecting the trade orthodoxy, before searching for new policy openings, which would characterise Oxfam's subsequent research trajectory (see Watkins 1995a, 1995b; LeQuesne 1996). As he expressed it, the aim was to 'shift trade debates from abstract discussions about prices to something that was really about political decisions and negotiations'. ${ }^{12}$

By returning to the framework on scientific capital, we can provide some enhanced perspective on this period. One aspect concerns how Oxfam, along with other trade-facing CSOs, arguably did not possess the 'authentic' scientific capital to not only shape the GATT agenda, but simply to monitor policy developments within a system where capitalist elites were searching for new

\footnotetext{
10 Duncan Green, former Head of Research, Oxfam International, interview with the author, London, 27 May 2011; and Emily Jones, former Policy Advisor, Oxfam International, interview with the author, Oxford, 26 October 2011.

11 By comparison, activism on trade policy within US and Canadian-based CSO networks was arguably more mature, reflecting interest in the Canada-US Free Trade Agreement and the negotiations for the North American Free Trade Agreement (NAFTA). For instance, from the late 1980s, at the Institute for Agriculture and Trade Policy (IATP), Mark Ritchie was influential in alerting others to the emerging GATT agenda. At Public Citizen, Lori Wallach was important in tracking the GATT agenda from Geneva and forming alliances with other activists, leading in 1992 to the establishment of the Citizen's Trade Campaign (CTC) (Aaronson 2001)

12 Watkins, interview with the author.
} 
forms of commodity value. ${ }^{13}$ In one sense, this degree of ignorance of the GATT agenda was caused by its aforementioned club-like environment, a social world which was difficult to enter, scrutinise, and communicate to other outsiders. Such repercussions bring to mind Bourdieu's (1975) point that the internal valorisation and refinement of scientific capital within a field, including all the competition between authorised experts for domination, tends over time to raise the entry requirements for new pretenders. By the mid-1990s, this problem became particularly acute due to a significant thickening of the legal-normative structure of rulemaking and culture in the new WTO (Howse 2002; Pauwelyn 2005). It follows, therefore, that higher barriers to entry will often reduce the prospect of agents nurturing more profound subversion strategies and increase the likelihood of contests remaining within the boundaries of the orthodoxy; that is, not significantly disturbing the major principles of legitimacy in the field. This tension ultimately reflects how Oxfam is caught in a struggle to acquire professional legitimacy with two different types of audience: (1) the relatively secluded space of bureaucratic trade formulation (which was often resistant to any engagement with civil society) and, at the same time; (2) a diverse external world of constituents, critics, and media (some of whom may not adequately grasp the precise constitution of the scientific capital under deliberation and, as a course of strategy, demand more 'radical action'). In the language of social activism, this central point has been summarised by Edwards (1993: 169-170):

\begin{abstract}
'NGOs face a real dilemma here: on the one hand, if they try to "speak the same language" as the targets of their advocacy and go about their work quietly and constructively, they risk being co-opted or generating a superficial response, there being no wider pressures for more fundamental change. On the other hand, if NGOs opt for a more radical path, they risk being marginalised, because their recommendations are so far
\end{abstract}

\footnotetext{
${ }^{13}$ In the context of the Uruguay Round, the US, Japan, and the EU were focused on highly prized sectors and issues, such as services trade, financial investment, and intellectual property rules. Encouraged by leading corporate lobby associations within these sectors, trade policy began to move 'beyond the border' to penetrate domestic regulations in more profound ways. For studies on these issues, see Drake and Nicolaïdis (1992), and Sell (2003).
} 
outside the intellectual and ideological framework of the prevailing orthodoxy that they are simply ignored'.

This is, of course, an old historical problem, one that is often cast as between reformist versus revolutionary modes of advocacy. I would suggest that the gradual shift towards enhanced professionalisation within Oxfam around the turn of the century can be interpreted as an effort to negotiate - although never entirely reconcile - this tension between 'insider' versus 'outsider' strategies in the politics of advocacy. As I will explain in the next section, this work has consisted of nurturing three sets of skills. First, in order to gain recognition in a social space dominated by orthodox experts, Oxfam has learnt how to demonstrate command of major agendas and techniques of scientific capital prized in the trade policy world. Second, to distinguish its brand of social critique, with a view to consolidating its position in the arguing universe, this research labour has become focused on isolating discrepancies, or indeed potential contradictions, between an idealised model of trade (such as found in neoclassical theory or in the rhetoric of trade bureaucracies) and concrete practices. Third, only following this critique can a further method be deployed: converting the newly minted scientific capital (in the form of reports and briefs) into digestible, communication packages for the wider world of observers and allies beyond the domain of established experts. To illustrate these tendencies in action, I advance forward to the early 2000s and focus on a particular illustration: the construction of an influential report, Rigged Rules and Double Standards (2002) which formed part of a major Oxfam campaign called 'Make Trade Fair'.

\section{PLAYING THE TRADE POLICY GAME}

As with any actor aiming to shape the distributional effects of capitalism, Oxfam is positioned within larger epistemic and material structures which, in turn, constrain or enable the scope for action. Around the turn of the millennium, in the context of the ascendency of neoliberal norms and the specific efforts of the US and the EU to launch a new WTO round of negotiations, the trade policy 
landscape included many contentious problems. For instance, the pressures experienced by many developing countries in the WTO became the subject of much controversy, related to both the process of negotiations and the substance of rules (Wade 2003; Jawara and Kwa 2004; also see Lang 2011). On the other hand, however, because the WTO had become a lightning rod for CSO and popular criticism - embracing labour unionists, environmentalists, and social justice campaigners - a window of opportunity had opened for cultivating a more sustained critique of the trade system and its inequities (McNally 2002; Smith and Johnston 2002; Steger and Wilson 2012). ${ }^{14}$ Within this broader alter-globalisation movement and, in particular, following the collapse of the Seattle WTO Ministerial Conference in 1999, Oxfam expanded its trade advocacy work. For example, in terms of the volume of outputs, from 1999 to 2001, 26 publications focused on trade politics, including traditional topics such as agriculture, but also concerns related to the WTO's institutional design, intellectual property rules, and gender-related questions. By contrast, over the entire period from 1980 to 1998, 19 publications featured explicit trade discussions.

From early 2000, Oxfam began planning a more ambitious international trade campaign which would be launched in the first half of 2002. Key people involved in these discussions included Phil Twyford, Director for Advocacy for Oxfam International based in Washington DC; Justin Forsyth, Campaign and Policy Director; Phil Bloomer, Head of Advocacy and Public Policy; Penny Fowler, Trade Policy Adviser, and Kevin Watkins, still Head of Research. ${ }^{15}$ The production of a major report on trade policy was viewed as central to the potential effectiveness of the campaign. In one early draft strategy, it argues that the publication should be viewed as 'not just a research exercise, but as

\footnotetext{
${ }^{14}$ Other domestic and international political opportunities also helped to create the conditions for a more favourable dialogue between trade and development policy which, in turn, was exploited by Oxfam. A number of prominent policymakers, as well as international bodies (such as the Food and Agriculture Organization of the United Nations and the South Centre), were increasingly calling for 'more development' in the WTO system. For instance, the Brazilian Ambassador, Celso Amorim, often argued that the system suffered from a 'development deficit'. In the UK, the Labour government devoted more financial and political resources to development policy. For example, Clare Short, the UK Secretary of State for International Development (1997-2003), was perhaps the first official to attach the term 'development' to the envisaged 'new round' of trade talks (which would be launched in Doha in 2001).

${ }^{15}$ These individuals only represent the core coordinators operating through a new Oxfam International Trade Campaign Working Group. By late 2001, in relation to Oxfam GB operations alone, there was a team of around 25 members focused on trade issues.
} 
an opportunity to develop a dynamic process of dialogue with country programmes and partners, allies, and international coalitions'. There was a call to 'elaborate a broad consensus position on trade', one which argues that the potential benefits for developing countries are being lost due to 'inappropriate trade rules [and] double standards'. What it claimed was needed, instead, are 'markets which work for the poor'. In turn, the draft proposed that this larger argument could be prosecuted through a 'strong critique' of existing theories on the links between trade, growth, and equity; as well as examining focused topics, such as around intellectual property rights and the impacts of agricultural dumping. Overall, it suggested that that '[w]e need to develop a stronger and more comprehensive analysis of the relationship between trade and poverty; and we need to develop a comparative advantage in capturing the human dimensions of trading activity'. ${ }^{16}$ On wider campaigning and messaging, there was a particular debate on the different ways to mobilise policy and public interest, including how and when to keep communications 'complex' or 'simple'. ${ }^{17}$

In April 2002, Oxfam launched Rigged Rules and Double Standards as part of its larger Make Trade Fair campaign. Kevin Watkins wrote the report, with the exception of one chapter penned by Penny Fowler. ${ }^{18}$ In the acknowledgements, 12 individuals are given special credit for their contribution. On background studies that were commissioned or incorporated into the research, recognition is given to a further 69 individuals and entities. Amartya Sen, Honorary President of Oxfam, added a foreword. Running to over 270 pages, and organised around nine chapters, it sets out a case that global trade relations magnify inequalities and contribute to poverty. It posits that the debate on trade policy is 'dominated by ritualistic exchanges' between two 'fundamentalist camps': 'globaphiles' who argue that 'globalisation works for the poor' and 'globaphobes' who suggest that 'trade is inherently bad for the poor'. The report

\footnotetext{
16 'International Trade Campaign: Concept Paper for Research and Report', attached to email communication from Kevin Watkins, 'Ol Trade Campaign', sent November 7, 2000. Oxfam Archives, Oxford University, Bodleian Library, Special Collections (MS. Oxfam PRG/8/3/2/11).

17 'Trade Campaign Strategy', Draft Version May 16, 2000. Oxfam Archives, Oxford University, Bodleian Library, Special Collections (MS. Oxfam PRG/8/3/2/11).

18 Penny Fowler holds a BSc in Economics and Politics from the University of Bristol and an MSc Economics for Development from the University of Oxford.
} 
argues that both orientations 'fly in the face of the evidence - and neither offers any hope of the future' (Oxfam International 2002: 7, 22). Through this framing, Rigged Rules and Double Standards (2002) tries to chart a middle ground: on the one hand, using examples such as Vietnam and Uganda, it argues that export success plays a role in poverty reduction and, therefore, developing countries should have enhanced market access opportunities to export their goods to developed countries (chapters 1 and 2). On the other hand, however, using evidence from World Bank and IMF conditionality agreements, it argues that rapid import liberalisation has often been detrimental to poverty reduction, citing China as a country which gradually liberalised. The theme of 'double standards' between a richer North and a poorer South is examined with many illustrations, including the impact of agricultural regulations in developed countries, intellectual property rules, and the behaviour of some transnational corporations (chapters 4, 7 and 8).

In order to better understand the composition and social reactions of Rigged Rules and Double Standards (2002), as a example of Oxfam's wider professionalisation, we can return to conceptualise the strategies and objects of scientific capital. Here, I would like to elaborate upon Bourdieu's theorising to consider three dimensions of scientific capital in this case. The first dimension would be the academic qualifications of the Oxfam analyst. As an 'admission ticket' to the social space of trade policy deliberation, the degree certificate, notably in economics or development studies, confers upon the analyst a distilled, legally sanctioned form of recognition. While essential for acquiring a position in the group and demonstrating foundational expertise, policy impact can only be potentially realised when the analyst cultivates another dimension of scientific capital: the production of new knowledge. Within the campaign and research outputs for Make Trade Fair, signifying the ability to absorb and synthesis large literatures - including, notably, sources from the World Bank, OECD, and mainstream economics - was a key way in which Oxfam tried to earn the label of 'serious NGO' in the wider world of experts. ${ }^{19}$

\footnotetext{
${ }^{19}$ At the WTO Secretariat and in diplomatic trade circles, the term 'serious' has been invoked as a loose label for those civil society groups who are perceived to be 'constructive' in some way to the trade system, such as producing 'substantive research', although the identification of 'non-serious' groups is often not
} 
Rigged Rules and Double Standards (2002) is furnished with many supporting graphs and figures, in the process appealing to the deeper 'trust in numbers' and the prestige associated with quantification (Porter 1995). Overall, as noted, it makes a significant normative commitment that trade liberalisation can be a 'powerful motor for the reduction of poverty', but that this promise is not being adequately fulfilled (Oxfam International 2002: 5). As Hopewell (2015) has suggested, this stance could be read as Oxfam embracing arguments which carry a 'neoliberal' imprint and not, by contrast, calling for a rejection of the WTO regime (a demand seen in other groups, such as the Vía Campesina movement or Greenpeace in the late-1990s) (Ilcan and Lacey 2006).

As a type of recognition, scientific capital is acquired through mastering the knowledge of the existing orthodoxy, yet social critique, and thus potential strategies of subversion, can only be cultivated through isolating and teasing out the vulnerabilities contained within the orthodoxy. To borrow from Boltanski and Chiapello (2006), such activity tends to probe the tensions, ambiguities, and potential contradictions which exist between the depictions of orthodoxy and how it is materially lived and experienced. In other words, the Oxfam research analyst seeks ways that will put the orthodoxy under greater scrutiny; sometimes to 'tighten up' the empirical rigour of certain causal relations, at other times, to more forcefully destablise so-called 'myths' or larger narratives. As one Oxfam representative expressed it, 'there is often an effort to reverse engineer the status quo within these research projects, that is, to look at evidence on the ground as a way to question the presumption that free trade is inherently good'. ${ }^{20}$ This subversion strategy can also take the form of mimicking analytical models and methods used by conventional experts, such as a Trade Liberalisation Indicator used to dispute trade openness studies (chapter 5) or a Double Standards Index used to highlight forms of protectionism practiced by the US, EU, Canada, and Japan (chapter 4) (Oxfam International 2002). In short, all this research aims to stir a sense of moral indignation fueled by two major claims: (1) that trade rules are causing social suffering which could be

specified. Bernard Kuiten, Head of External Relations, World Trade Organization, interview with the author, February 16, 2016. Also see Hopewell (2015).

${ }^{20}$ Oxfam Policy Advisor, interview with the author, Oxford, March 12, 2012. 
undone; and (2) that certain representations in political and expert discourse are inauthentic and, thus, critique is needed, in the spirit of Marx, to expose a distinction between truth and illusion.

A third dimension of scientific capital would involve analysing how this foundational expertise is now complemented by a range of presentational and branding tactics which, in turn, often help to reinforce the authority of the original research. These methods are primarily part of playing the 'outsider' game: that is, seizing the attention of relevant media to galvanise public sympathy. This can be seen in how the ambition to 'humanise' trade in campaigning literature frequenting incorporates quotes from 'real people', such as farmers and labourers in developing countries who are interviewed by local Oxfam staff. As elements within the text, they sometimes exist in an ambiguous relationship with the related analysis: either as enlightening the 'sterilised' social scientific knowledge with a human voice or, in other contexts, seeming to stand apart as some 'authentic' source of revelation. Elsewhere, the appeal to so-called 'killer facts and graphics' is particularly important as a way to quickly communicate a sense of injustice to journalists, targeted officials, and other constituents. For instance, in the Make Trade Fair campaign, the most frequently heard Oxfamcomposed 'killer fact' was the following: 'Every EU cow receives over $\$ 2$ per day in support and subsidies, more than the income of half the world's people'. As noted, this particular tactic has been used since at least the 1980s, but by the early 2000s it was further expanded, refined, and promoted (see Green 2012 for detail on the technique; and Green and Bloomer 2011). Finally, with the lowering of technology costs and the turn to a more visual, screen-based culture, the campaign was accompanied by a raft of promotional images, materials, and websites which helped to 'keep the brand on message'. Within this activity, the involvement of celebrities, such as Colin Firth and Michael Stipe, helped to attract attention and enhance a media dialogue (more broadly on such trends, see Dogra 2012).

When one turns to evaluate the wider impact and effectiveness of Rigged Rules and Double Standards (2002), there were a range of immediate responses. In one sense, within the media, the report was favourably received, with Oxfam 
internally recording all publicity, along with privately received comments. ${ }^{21}$ Strong forms of support quickly arrived from other leading CSOs, such as Christian Aid and CAFOD. Within the WTO talks, the publication was seized upon by countries within the Cairns Group, a coalition of countries with strong agricultural exporting interests (a result which was commended in one internal Oxfam email exchange). ${ }^{22}$ A number of developing countries who historically contested rules on OECD agricultural subsidies, such as Brazil, also praised the report, along with an emerging group of West African cotton-producing states (who would be the subject of a related Oxfam campaign from 2003). In the most detailed engagement from a single policy actor, the European Commission issued a 32-page response in which it congratulated the report for being 'substantive' and 'well-researched', although criticised the claims that the EU was the most protectionist major trading power (European Commission 2002). As the Head of External Relations at the WTO expressed it when reflecting upon this period: 'People in the WTO stood up and took notice of this report. Members read it. Oxfam was viewed as being a mainstream NGO. I think that it altered the debate because, in essence, it broadly respected the system and its disciplines before arguing for change. In my view, it is still a textbook example or education of how research-based advocacy can actually make a difference'. ${ }^{23}$

At the same time, however, the report also generated considerable criticism from other CSOs who argued that Oxfam had placed too much focus on market access to richer countries, an emphasis which appeared to align with the reasoning of conventional trade experts. For instance, Walden Bello, Executive Director for Focus on the Global South, suggested that the framing between

\footnotetext{
21 This process of documenting feedback on the campaign can, indeed, be viewed as another aspect of the culture of professionalisation with Oxfam. It represents the development of a kind of embryonic managerialism within the group, a trend that would become more pronounced by the late 2000s.

${ }_{22}$ Mark Fried, 'Agriculture and Trade Meeting in Ottawa', email communication, sent May 6, 2002. Oxfam Archives, Oxford University, Bodleian Library, Special Collections (MS. Oxfam PRG/8/3/2/11). Within this email, it includes the following remarks on a meeting attended by Fried which included representatives from the Cairns Group: 'When I made my presence know, I was deluged with requests for the report, and the heavy hitters sought me out to congratulate Oxfam for taking the globalization debate to the level of specific policy changes. I gather we have made ourselves heard at that level. Though it seems they hear what they want to hear. NGO allies heard only "market access"; this group heard only "end to subsidies"'. Established in 1986, the Cairns Group is a diverse coalition of 20 major agricultural exporting countries. Prominent members include Argentina, Australia, Brazil, Canada, South Africa, Thailand, and Uruguay. ${ }^{23}$ Bernard Kuiten, Head of External Relations, World Trade Organization, Geneva, interview with the author, February 16, 2016.
} 
'globaphiles' versus 'globaphobes' was a caricature, a distinction which risked creating divisions among the larger alter-globalisation movement. In Bello's mind, Oxfam needed to adopt a long-term, aggressive strategy of 'derailing' the WTO as an engine of corporate-led capitalism, rather than searching for discrepancies within existing rules as part of a limited, 'winnable' campaign (Bello 2002). Patrick Bond, co-director for Food First, argued that the report was emblematic of how Oxfam had gradually drifted towards an 'insiderist strategy' on policy, one which tended to undermine the approach to 'food sovereignty' promoted by many other groups (Bond 2002). A similar critique was also made by the influential environmental activist Vandana Shiva who suggested that Oxfam had made a 'failed attempt to mix two paradigms - one which gives precedence to people's democracy, another which gives precedence to trade, commerce, markets'. The result was a 'schizophrenic analysis' as the group tried to position itself, through a method of political triangulation, as being a 'moderate' opinion on trade policy analysis (Shiva 2002). It is also worth noting that some of these points were also expressed within Oxfam. For example, in the American and Belgium affiliates, some voices argued against not only the dichotomy between 'globaphiles' and 'globaphobes', but also how part of the promotion of the campaign was operating within elite networks of power (such as targeting officials at the WTO). ${ }^{24}$

It is this very contestation around Oxfam's intellectual strategy on trade policy which brings to the surface certain tensions and anxieties stemming from the dynamics of professionalisation. On the one hand, in the shadow of its earlier, limited policy impact, I have argued that the group, led by particular entrepreneurs, sought to strengthen valued forms of scientific capital, resulting in an enhanced degree of political recognition around the turn of the century. On the other hand, however, this move towards professionalisation - which pivoted around a mild acceptance of the prevailing trade orthodoxy and some

\footnotetext{
${ }^{24}$ Email communication from Xavier Declercq, Advocacy Director, Oxfam-Solidarity, 'FW: Meeting with Nicolla Bullard (Focus) on Trade Campaign', April $30^{\text {th }}, 2002$, Oxfam Archives, Oxford University, Bodleian Library, Special Collections (MS. Oxfam MS. Oxfam PRG/8/3/2/12). For an example of discord with Oxfam America, Severina Rivera, a senior trade analyst within the affiliate, resigning in protest at how the Make Trade Fair campaign was emphasising market access as part of its arguments. See Little, M., 'Oxfam Fair Trade Policy Hit as US Adviser Quits', Third Sector, May 15, 2002.
} 
of its justificatory methods - also provoked criticism that Oxfam had 'lost' a sense of its critical calling. Some authors have suggested that such shifts can be cast in terms of how CSOs may be 'incorporated into a neoliberal model of civil society' (Kamat 2004: 155; also see earlier debates summarised by Dichter 1989; as well as Dauvergne and LeBaron 2014; Hopewell 2015). While this depiction may give us a basic anchor within late capitalism, my argument is that a more subtle reading of activist subjectivity is needed, whereby the dance between power and principles of social justice can be represented through a new ideal-type category, labelled here as the 'critical technician'. In other words, while the term neoliberalism offers a 'descriptive shell' for analysis (Venugopal 2015: 182), it also suffers under the burden of being tied to a vast galaxy of objects and processes. Here, in conclusion, I sketch out features of this concept of the critical technician and suggest its relevance for refreshing the larger study of the politics of professionalisation and expertise within IPS.

\section{A NEW CONCEPT OF 'REFORMIST' ACTIVISM: THE CRITICAL TECHNICIAN}

Across many social fields, through the labour of dominant cultural producers, the recognised orthodoxy works to demarcate the boundaries of the 'politically possible' and, within this arduous activity, often tends to struggle with 'deviant beliefs' in order to better manage the reproduction of the orthodoxy (Berger and Luckmann 1967; Bourdieu 1977). The strength of any orthodoxy - at times a defining feature - centres on how it reconfigures itself against other potential orthodoxies, opinions that are positioned as heterodox by virtue of having a marginalised status (Berlinerblau 2001). Within the wide spectrum of potential heterodox protest actions, my concern in this article has been focused on those strategies which play with a selective appropriation, critique, and distortion of practices defined by the larger orthodoxy, rather than an outright rejection of the mainstream. Through this positioning, the heterodox voice tries to be 'communicable' to the orthodoxy and may appear, via many arguments, to be 'making political sense' (when defined in relation whatever is judged to be conventional or 'best practice'). At the same time, such agents also try to retain a degree of autonomy from dominant powers - ideologically, financially, 
socially, spatially - although how this distance is produced and evaluated is often contested. Rather than always adopting the larger concepts of CSO (or $N G O$ ) - categories that encompass an extraordinary plethora of entities and interests, both progressive and regressive - I would suggest here that the notion of the critical technician offers a more precise vehicle for exploring dispositional tendencies found within this class of professionalised civil society agents. In this regard, beyond the case of Oxfam, I am also thinking here of how other groups, such as Amnesty International, Save the Children, or Transparency International, will likely contain figures who fit within the mould of the critical technician (for instance, on Amnesty's culture, see Hopgood 2006).

My argument is that the critical technician tends to emerge under certain conditions. Through the degree certificate, such figures have already undergone a process of academic consecration which, in turn, will enable legitimate passage into organisations where scientific capital is prized. Within their professional life, the critical technician must demonstrate an energy to examine the shifting contents and fault lines within the latest policy orthodoxy, as well as, to the extent possible, the theoretical underpinnings and rulemaking legacies which have produced such orthodoxy. Due to the increased complexity of policy knowledge, such figures will often mimic established experts by steering towards specialised topics in order to acquire recognition, although the depth of this specialisation is always tempered by a need to 'deliver expertise' within resource-limited projects and political windows of opportunity. If a declared critical technician does not possess the capacity to X-ray the body of the policy orthodoxy, to understand the relations between its political joints, they will likely be questioned or ignored by authorised experts in the field (as with the phrases 'not serious', 'no substantive research' etc.). In other words, an agent who deviates too far from the orthodox 'justificatory tests' of the field will tend to be overlooked by those who occupy a privileged position (Boltanski and Chiapello 2006). This pressure on the critical technician to broadly conform may, over time, shape a cautious temperament, based upon the historical experience of learning how to test 'politically viable' policy propositions, as well as managing ties of acquaintance and dependence with authorised experts in established institutions. 
At the same time, as documented in the Oxfam case, the critical technician can only arise if they engage in the articulation of heterodox critique and, thus, draw out and police a distinctive space of argument. At a normative level, in contrast to the presumed 'politically neutral' and 'sterile' calculations of orthodoxy, the critical technician will often appeal to alternative sources of authenticity, notably by reactivating the historical critique of capitalism as a system which undermines the realisation of social justice. This ethical appeal, in turn, opens the potential for investigating 'missing' topics, experiences, or categories of perception that are marginalised by orthodox policy knowledge. Yet because the critical technician has already prioritised their dance with the orthodox partner (combined with a latent anxiety of desiring invites to future dances), they will often face opposition from agents who are closer to the radical heterodox pole in the universe of argument (Bourdieu 1977). Such frictions can occur at many points and stages. Under such circumstances, the critical technician is confronted with accusations that their work still carries limited aspiration, with ideas that are too wedded to the mainstream; in other words, a dilution of some (previous) radical sensibility or spirit in order to occupy the 'middle ground'. However, in keeping with the dominant sociological tendencies of group-making, such tensions may subside where critical technicians coalesce together, within organisations or wider networks and, in the process, forge a collective professional identity which is removed from more radical alternatives.

The category of the critical technician does share some affinity with Gramsci's idea of the organic intellectual. First, the notion of the critical technician dovetails with Gramsci's larger argument that the figure of the intellectual has undergone expansion and disaggregation under state-led capitalism, resulting in the emergence of rival organic intellectuals, representing different social groups, who intersect and compete with the stratum of traditional intellectuals. Second, similar to the concept of the organic intellectual, the critical technician is also a character who must be willing to participate in the practical struggle for hegemony, to be politically 'directive' as well as 'specialized' as Gramsci put it, in contrast to the traditional intellectual who often depict themselves as 
autonomous and removed from explicit social responsibility. The critical technician is thus concerned with engaging with a wider audience beyond the intellectual elite; to be a "permanent persuader" and not just a simple orator' (Gramsci 1971: 10). Third, in a manner similar to Gramsci's thinking, the critical technician, by virtue of their historical dominated position, will be concerned with dislodging the arbitrary construction of the common sense, rather than viewing it as an inevitable reality. In sum, as Stuart Hall has expressed it, it is the job of the organic intellectual to know more than the traditional intellectuals do: really know, not just pretend to know... to know deeply and profoundly (Hall 1996: 268).

However, I also view the concept of the critical technician as probing other features within the political competition for contemporary expert authority. At one level, in contrast to classical Gramscian analysis, the category does not presume a particular class-bound foundation of selfawareness and, in particular, certainly does not automatically imply working class or socialist party origins, nor any kind of general revolutionary zeal. Indeed, compared to Gramsci, the politics and working methods of certain critical technicians can often appear rather tame, quiet and, therefore, in keeping with the label of 'reformism'. Elsewhere, informed by the empirical discussion in this article, whereas Gramsci allows conceptual space for the organic intellectual to pursue a variety of practices, the concept of the critical technician is designed to highlight how the struggle to mobilise contemporary scientific capital now embraces some distinctive representation strategies (such as the use of new media, images, and branding). In other words, the development of an 'abstract mathematical spirit' (Gramsci 1971: 10) is still a necessary core within the modern critical technician, but has now been complimented by communication strategies which are, in turn, reflective of an advanced cultural capitalism which celebrates represenation and the circulation of symbolic goods and services (Bourdieu 1984, 2005). ${ }^{25}$

\footnotetext{
${ }^{25}$ A wider comparison between Gramsci and Bourdieu is arguably overdue, including on the question of intellectuals. Bourdieu was often coy and overly dismissive about Gramsci's sophisticated Marxism and where precisely he positioned himself in relation to the author of the Prison Notebooks. For the better comparative analysis, see Buraway (2012), and Swartz (2013).
} 
In sum, this article has sought to advance different arguments of relevance for IPS scholarship. On conceptual innovations, I have explicated the utility of Bourdieu's notion of scientific capital for grasping the relations between expertise and power within cultures of professionalisation, a framework which has received comparatively little attention in IPS debates. My aim has been to apply scientific capital to not only classic empirical objects studied by Bourdieu, notably the struggle to construct authorised languages, but also to reveal how such capital is distilled into items of popular consumption. Through the empirical investigation into Oxfam, I have explained how a professionalised activist subjectivity has became increasingly normalised. The concept of the critical technician is offered as a way to dissect the working practices of policyfacing agents who have otherwise struggled to acquire status within established circuits of powers. For IPS, I would suggest that the dispositional attributes of the critical technician are found in many other organisations and policy fields beyond the Oxfam example, such as human rights or environmental politics. Further research could explore how the conduct of such players has involved practicing a range of skills in order to acquire and sustain authority, such as aptitudes of discretion and deference, or new qualities of managerialism. A final contribution of this article would involve encouraging further connections at the nexus between IPS and IPE. Both fields have individually dissected global political processes, but it is only through a richer intellectual cross-pollination and dialogue that we can attend to the multi-faceted dimensions of capitalism and its influence on international relations. 


\section{REFERENCES}

Aaronson, S. A., Taking Trade to the Streets: The Lost History of Public Efforts to Shape Globalization (Ann Arbor: The University of Michigan Press, 2001).

Abbott, A., The System of Professions: An Essay on the Division of Expert Labor (Chicago: University of Chicago Press, 1988).

Abdelal, R., Blyth, M., and Parsons, C. (eds), Constructing the International Economy (Ithaca: Cornell University Press, 2010).

Anderson, I., 'Global Action: International NGOs and Advocacy', in Rugendyke, B. (ed.), NGOs as Advocates for Development in a Globalising World (Abingdon: Routledge, 2007).

Barnett, M. and Finnemore, M. Rules for the World: International Organizations in Global Politics (Ithaca: Cornell University Press, 2004).

Bello, W., 'The Oxfam Debate: From Controvesy to Common Strategy', South Bulletin, $36,13-16$.

Berger, P. L. and Luckmann, T., The Social Construction of Reality: A Treatise in the Sociology of Knowledge (New York: Anchor, 1967).

Berling, T. V., The International Political Sociology of Security: Rethinking Theory and Practice (Abingdon: Routledge, 2015).

Berlinerblau, J., 'Toward a Sociology of Heresy, Orthodoxy, and Doxa', History of Religions, 40 (2001), 4, 327-351.

Bernhard, S., 'Beyond Constructivism: The Political Sociology of an EU Policy Field', International Political Sociology, 5 (2011), 4, 426-445.

Best, J., The Limits of Transparency: Ambiguity and the History of International Finance (Ithaca: Cornell University Press, 2005).

Best, J., Governing Failure: Provisional Expertise and the Transformation of Global Development Finance (Cambridge: Cambridge University Press, 2014).

Bigo D., 'Pierre Bourdieu and International Relations: Power of Practices, Practices of Power', International Political Sociology, 5 (2011), 3, 225-258.

Bigo, D., 'Sociology of Transnational Guilds', International Political Sociology, 10 (2016), 4, 398-416.

Black, M., A Cause for Our Times: Oxfam The First 50 Years (Oxford: Oxford University Press, 1992).

Blyth, M., Great Transformations: Economic Ideas and Institutional Change in the Twentieth Century (Cambridge: Cambridge University Press, 2002).

Boltanski, L. and Chaipello, E., The New Spirit of Capitalism (London: Verso, 2006).

Bond, P., 'Moderates Wilt But Radical South Africans Struggle On', ZNet Daily Commentaries, April 17, 2002.

Bourdieu, P., 'The Specificity of the Scientific Field and the Social Conditions of the Progress of Reason', Social Science Information, 14 (1975), 6, 19-47.

Bourdieu, P., Outline of a Theory of Practice (Cambridge: Cambridge University Press, 1977).

Bourdieu, P., Distinction: A Social Critique of the Judgment of Taste (London: Routledge, 1984).

Bourdieu, P., 'The Forms of Capital', in Richardson, J. G. (ed.), Handbook of Theory and Research for the Sociology of Education (New York: Greenwood Press, 1986).

Bourdieu, P., 'Social Space and Symbolic Power', Sociological Theory, 7 (1989), 1, 14-25.

Bourdieu, P., 'The Peculiar History of Scientific Reason', Sociological Forum, 6 (1991), 1, 3-26.

Bourdieu, P., Science of Science and Reflexivity (Cambridge: Polity Press, 2004).

Bourdieu, P., The Social Structures of the Economy (Cambridge: Polity, 2005). 
Burawoy, M., 'The Roots of Domination: Beyond Bourdieu and Gramsci', Sociology, 46 (2012), 2, 187-206.

Chwieroth, J., Capital Ideas: The IMF and the Rise of Financial Liberalization (Princeton: Princeton University Press, 2010).

Clark, J., For Richer For Poorer: An Oxfam Report on Western Connections with World Hunger (Oxford: Oxfam, 1986).

Clark, J., 'Democratising Development: NGOs and the State', Development in Practice, 2 (1992), 3, 151-162.

Coote, B., The Hunger Crop: Poverty and the Sugar Industry (Oxford: Oxfam, 1987).

Coote, B., The Trade Trap: Poverty and the Global Commodity Markets (Oxford: Oxfam, 1992).

Cox, R. W., 'Ideologies and the New International Economic Order: Reflections on Some Recent Literature', International Organization, 33 (1979), 2, 257-302.

Cross, M. K. D., 'Rethinking Epistemic Communities Twenty Years Later', Review of International Studies, 39 (2013), 1, 137-160.

Curzon, G. and Curzon, V., 'GATT: Traders' Club' in Cox, R. W. and Jacobson (eds), The Anatomy of Influence: Decision Making in International Organizations (New Haven: Yale University Press, 1973).

Dar, S. and Cooke, B. (eds), The New Development Management: Critiquing the Dual Modernization (London: Zed Books, 2008).

Dauvergne, P. and LeBaron, G., Protest Inc.: The Corporatization of Activism (Cambridge: Polity Press, 2014).

Della Porta, D. (ed.), The Global Justice Movement: Cross National and Transnational Perspectives (Boulder, CO: Paradigm, 2007).

Dezalay, Y. and Garth, B. G., The Internationalization of Palace Wars: Lawyers, Economists, and the Contest to Transform Latin American States (Chicago: University of Chicago Press, 2002).

Dezalay, Y. and Garth, B. G., 'Hegemonic Battles, Professional Rivalries, and the International Division of Labour in the Market for the Import and Export of StateGoverning Expertise', International Political Sociology, 5 (2011), 3, 276-293.

Dezalay, Y. and Madsen, M. R., 'In the "Field" of Transnational Professionals: A PostBourdieusian Approach to Transnational Legal Entrepreneurs', in Seabrooke, L. and Henriksen, L. F. (eds), Professional Networks in Transnational Governance (Cambridge: Cambridge University Press, 2017).

Dichter, T. W., 'Development Management: Plain or Fancy? Sorting Out Some Muddles', Public Administration and Development, 9 (1989), 4, 381-393.

Dogra, N., Representations of Global Poverty: Aid, Development and International NGOs (London: I. B. Tauris 2012).

Drake, W. and Nicolaïdis, K., 'Ideas, Interests, and Institutionalization: "Trade in Services" and the Uruguay Round', International Organization, 46 (1992), 1, 37-100.

Dür, A. and De Bièvre, D., 'Inclusion without Influence? NGOs in European Trade Policy', Journal of Public Policy, 27 (2007), 1, 79-101.

European Commission, 'Rigged Rules and Double Standards - Trade, Globalisation and the Fight Against Poverty', Comments from the Commission, April 17, 2002.

Edwards, M., "'Does the Doormat Influence the Boot?": Critical Thoughts on UK NGOs and International Advocacy', Development in Practice, 3 (1993), 3, 163-175.

Fourcade, M., 'The Construction of a Global Profession: The Transnationalization of Economics', American Journal of Sociology, 112 (2006), 1, 145-194.

Fourcade, M., Economists and Societies: Discipline and Profession in the United States, Britain, and France, 1890s to 1990s (Princeton: Princeton University Press, 2010).

Freidson, E., Professionalism: The Third Logic (Chicago: University of Chicago Press, 2001). 
Gamble, A., Crisis Without End?: The Unravelling of Western Prosperity (Basingstoke: Palgrave Macmillan, 2014).

Goode, W., 'The Theoretical Limits of Professionalization', in Etzioni, A. (ed.), The Semiprofessions and Their Organizations (New York: Free Press, 1969).

Gorman, E. H. and Sandefur, R. L., "'Golden Age," Quiescence, and Revival: How the Sociology of Professions Became the Study of Knowledge-Based Work', Work and Occupations, 38 (2011), 3, 275-302.

Gramsci, A., Selections from the Prison Notebooks (London: Lawrence \& Wishart, 1971).

Green, D., 'Creating Killer Facts and Graphics', Oxfam Research Guidelines (Oxford: Oxfam GB, 2012).

Green, D. and Bloomer, P., 'NGOs in Economic Diplomacy' in Woolcock, S. and Bayne, N. (eds), The New Economic Diplomacy: Decision-Making and Negotiation in International Economic Relations (Farnham: Ashgate Publishing, 2011).

Haas, P. M., 'Epistemic Communities and International Policy Coordination', International Organization, 46 (1992), 1, 1-35.

Haas, P. M., Epistemic Communities, Constructivism, and International Environmental Politics (Abingdon: Routledge, 2016).

Hall, S., 'Gramsci's Relevance for the Study of Race and Ethnicity', in Morley, D. and Chen, K.-H. (eds), Stuart Hall: Critical Dialogues in Cultural Studies (London: Routledge, 1996).

Hannah, E., 'The Quest for Accountable Governance: Embedded NGOs and Demand Driven Advocacy in the International Trade Regime', Journal of World Trade, 48 (2014), 3, 457-479.

Hannah, E., NGOs and Global Trade: Non-State Voices in EU Trade Policymaking (Abingdon: Routledge, 2016).

Hannah, E. and Scott, J., 'From Palais de Nations to Centre William Rappard: Raúl Prebisch and UNCTAD as Sources of Ideas in the GATTMTO', in Margulis, M. E. (ed.), The Global Political Economy of Raúl Prebisch (Abingdon: Routledge, 2017).

Hannah, E., Scott, J., and Trommer, S. (eds), Expert Knowledge in Global Trade (Abingdon: Routledge, 2016).

Hilton, M., McKay, J., Crowson, N., and Mouhot, J-F., The Politics of Expertise: How NGOs Shaped Modern Britain (Oxford: Oxford University Press, 2013).

Hilton, M., Crowson, N., Mouhot, J., McKay, J., A Historical Guide to NGOs in Britain: Charities, Civil Society and the Voluntary Sector Since 1945 (Basingstoke: Palgrave Macmillan, 2012).

Hocking, B., "Changing the Terms of Trade Policy Making: From the "Club" to the "Multistakeholder" Model', World Trade Review, 3 (2004), 1, 3-26.

Hopewell, K., 'Multilateral Trade Governance as Social Field: Global Civil Society and the WTO', Review of International Political Economy, 22 (2015), 6, 1128-1158.

Hopgood, S., Keepers of the Flame: Understanding Amnesty International (Ithaca: Cornell University Press, 2006).

Howse, R., 'From Politics to Technocracy - and Back Again: The Fate of the Multilateral Trading Regime', The American Journal of International Law, 96 (2002), 1, 94-117.

Howse, R. and Nicolaïdis, K., 'Democracy Without Sovereignty: The Global Vocation of Political Ethics', in Broude, T. and Shany, Y. (eds), The Shifting Allocation of Authority in International Law: Considering Sovereignty, Supremacy and Subsidiarity (Oxford: Hart Publishing 2008).

Ilcan, S. and Lacey, A., 'Governing Through Empowerment: Oxfam's Global Reform and Trade Campaigns', Globalizations, 3 (2006), 2, 207-225. 
Jawara, F., and Kwa, A., Behind the Scenes at the WTO: The Real World of International Trade Negotiations/The Lessons of Cancún (London: Zed Books, 2004).

Jones, K., 'Green Room Politics and the WTO's Crisis of Representation', Progress in Development Studies, 9 (2009), 4, 349-357.

Jordan, A. G. and Maloney, W., The Protest Business: Mobilizing Campaigning Groups (Manchester: Manchester University Press, 1997).

Kamat, S., 'The Privatization of Public Interest: Theorizing NGO Discourse in a Neoliberal Era', Review of International Political Economy, 11 (2004), 1, 155176.

Kennedy, D., A World Of Struggle: How Power, Law, and Expertise Shape Global Political Economy (Princeton: Princeton University Press, 2016).

Keohane, R. O. and Nye, J. S., 'The Club Model of Multilateral Cooperation and Problems of Problems of Democratic Legitimacy', in Porter, R. B., Sauvé, P., Subramanian, A., and Beviglia Zampetti, A. (eds), Efficiency, Equity, and Legitimacy: The Multilateral Trading System at the Millennium (Washington D.C.: Brookings Institution Press, 2001).

Kohler-Koch, B. and Finke, B., 'The Institutional Shaping of EU-Society Relations: A Contribution to Democracy via Participation?', Journal of Civil Society, 3 (2007), 3, 205-221.

Kauppi, N. and Madsen, M. R., 'Fields of Global Governance: How Transnational Power Elites Can Make Global Governance Intelligible', International Political Sociology, 8 (2014), 3, 324-342.

Kauppi, N. and Madsen, M. R. (eds), Transnational Power Elites: The New Professionals (Abingdon: Routledge, 2013).

Lamp, N., 'The Club Approach to Multilateral Trade Lawmaking', Vanderbilt Journal of Transnational Law, 49 (2016), 1, 107-190.

Lang, A. T. F., World Trade Law after Neoliberalism: Re-imagining the Global Economic Order (Oxford: Oxford University Press, 2011).

Larson, M. S., The Rise of Professionalism (Berkeley: University of California Press, 1977).

LeQuesne, C., Reforming World Trade: The Social and Environmental Priorities (Oxford: Oxfam International, 1996).

Lewis, D., The Management of Non-Governmental Development Organizations (Abingdon: Routledge, 2007).

Marceau, G. (ed.), A History of Law and Lawyers in the GATT/WTO: The Development of the Rule of Law in the Multilateral Trading System (Cambridge: Cambridge University Press, 2015).

McNally, D., Another World Is Possible: Globalization and Anti-Capitalism (Winnipeg: Arbeiter Ring Pub, 2002).

McNamara, K. R., The Currency of Ideas: Monetary Politics in the European Union (Ithaca, NY: Cornell University Press, 1999).

Meunier, S., 'Trade Policy and Political Legitimacy in the European Union', Comparative European Politics, 1 (2003), 1, 67-90.

Murphy, C., Emergence of the NIEO Ideology (Boulder, Colorado: Westview, 1984).

Murphy, H., The Making of International Trade Policy: NGOs, Agenda-Setting and the WTO (Cheltenham: Edward Elgar, 2010).

Narlikar, A., 'Evolving Trade Governance on the Formal-Informal Spectrum: The Case of the World Trade Organization', in Christiansen, T. and Neuhold, C. (eds), International Handbook on Informal Governance (Cheltenham: Edward Elgar Publishing, 2012).

O'Sullivan, K., 'The Search for Justice: NGOs in Britain and Ireland and the New International Economic Order, 1968-82', Humanity: An International Journal of Human Rights, Humanitarianism and Development, 6 (2015), 1, 173-187.

Oxfam GB, Oxfam Annual Report and Accounts 2000/2001 (Oxford: Oxfam GB 2001). 
Oxfam International, Rigged Rules and Double Standards: Trade, Globalisation and the Fight Against Poverty (Oxford: Oxfam International, 2002).

Parsons, T., 'The Professions and Social Structure', Social Forces, 17 (1939), 4, 457467.

Pauwelyn, J., 'The Transformation of World Trade', Michigan Law Review, 104 (2005), $1-66$

Porter, T. M., Trust in Numbers: The Pursuit of Objectivity in Science and Public Life (Princeton: Princeton University Press, 1995).

Raynolds, L. T., Murray, D. L., and Wilkinson, J. (eds), Fair Trade: The Challenges of Transforming Globalization (Abingdon: Routledge, 2007).

Roberts, S. M., Jones, J. P., and Fröhling, O., 'NGOs and the Globalization of Managerialism: A Research Framework', World Development, 33 (2005), 11, 1845-1864.

Scott, J., 'The Role of Southern Intellectuals in Contemporary Trade Governance', New Political Economy, 20 (2015), 5, 633-652.

Seabrooke, L., 'Identity Switching and Transnational Professionals', International Political Sociology, 8 (2014), 3, 335-337.

Seabrooke, L. and Henriksen, L. F. (eds), Professional Networks in Transnational Governance (Cambridge: Cambridge University Press, 2017).

Seabrooke, L., and Wigan, D., 'How Activists Use Benchmarks: Reformist and Revolutionary Benchmarks for Global Economic Justice', Review of International Studies, 41 (2015), 5, 887-904.

Sell, S. K., Private Power, Public Law: The Globalization of Intellectual Property Rights (Cambridge: Cambridge University Press, 2003).

Sending, O. J., The Politics of Expertise: Competing for Authority in Global Governance (Ann Arbor, MI: University of Michigan Press, 2015).

Shiva, V., 'Oxfam's Free Trade Recipe: Export at Any Cost', South Bulletin, 36, 10-13.

Sinclair, T. J., The New Masters of Capital: American Bond Rating Agencies and the Politics of Creditworthiness (Ithaca: Cornell University Press, 2005).

Smith, J. and Johnston, H. (eds), Globalization and Resistance: Transnational Dimensions of Social Movements (Lanham, MD: Rowman \& Littlefield Publishers, 2002).

Steger, M. B. and Wilson, E. K., 'Anti-Globalization or Alter-Globalization? Mapping the Political Ideology of the Global Justice Movement', International Studies Quarterly, 56 (2012), 3, 439-454.

Streeck, W., Buying Time: The Delayed Crisis of Democratic Capitalism (London: Verso, 2014).

Streeck, W., How Will Capitalism End? Essays on a Failing System (London: Verso, 2016).

Swartz, D. L., Symbolic Power, Politics, and Intellectuals (Chicago: University of Chicago Press, 2013).

Taylor, I. and Smith, K., United Nations Conference on Trade and Development (UNCTAD) (Abingdon: Routledge, 2007).

Tussie, D., The Less Developed Countries and the World Trading System: A Challenge to the GATT (London: Pinter, 1987).

Twose, N., Cultivating Hunger: An Oxfam Study of Food, Power \& Poverty (Oxford: Oxfam, 1984).

United Nations Conference on Trade and Development, Beyond Conventional Wisdom in Development Policy: An Intellectual History of UNCTAD 1964-2004 (Geneva: United Nations, 2004).

VanGrasstek, C., The History and Future of the World Trade Organization (Geneva: World Trade Organization, 2013).

Venugopal, R., 'Neoliberalism as Concept', Economy and Society, 44 (2015), 2, 165187. 
Wade, R., 'What Strategies are Viable for Developing Countries Today? The World Trade Organization and the Shrinking of 'Development Space', Review of International Political Economy, 10 (2003), 4, 621-644.

Watkins, K., Fixing the Rules: North-South Issues in International Trade and the GATT Uruguay Round (London: Catholic Institute for International Relations, 1992).

Watkins, K., The Oxfam Poverty Report (Oxford: Oxfam International, 1995a).

Watkins, K., Agricultural Trade and Food Security (Oxford: Oxfam GB, 1995b).

Weiler, J., 'The Rule of Lawyers and the Ethos of Diplomats: Reflection on the Internal and External Legitimacy of Dispute Settlement', in Roger B. Porter, Pierre Sauvé, Arvind Subramanian, and Americo Beviglia Zampetti (eds), Efficiency, Equity, and Legitimacy: The Multilateral Trading System at the Millennium (Washington D.C.: Brookings Institution Press, 2001).

Wilkinson, M. D., 'Lobbying for Fair Trade: Northern NGOs, the European Community and the GATT Uruguay Round', Third World Quarterly, 17 (1996), 2, 251-267.

Xu, Y-C. and Weller, P. M. (eds), The Governance of World Trade: International Civil Servants and the GATT/WTO (Cheltenham: Edward Elgar, 2004). 